\title{
Wyłączenie stosowania ulg \\ w spłacie w odniesieniu do \\ składek finansowanych przez ubezpieczonych niebędących płatnikami składek
}

\section{Inapplicability of Payment Reliefs to the Social Security Contributions Financed by the Insured Persons Other Than the Contribution Payers}

\begin{abstract}
Streszczenie. Składki finansowane przez ubezpieczonych niebędących płatnikami składek wyłączone są ze stosowania ulg w spłacie należności. Powoduje to trudności w spłacie zaległości. Propozycje zmian legislacyjnych zmierzają do ograniczenia tego wyłączenia na rzecz płatników składek zobowiązanych do przekazania środków do ZUS. Bardziej zasadne wydaje się ograniczenie wyłączenia w interesie ubezpieczonych, którzy są zobowiązani do sfinansowania składek opłacanych w terminie późniejszym niż prawidłowy.
\end{abstract}

Słowa kluczowe: ulgi; składki finansowane przez ubezpieczonych. 


\begin{abstract}
Social security contributions financed by the insured persons other than the contribution payers are excluded from the scope of applicability of payment reliefs. As a consequence difficulties in payment of arrears arise. Projects of legislative amendments tend to limit the scope of the exclusion in favour of the contribution payers obliged to pay the assets to the social security institution. It seems that the limitation of the exclusion in favour of the insured persons would be more appropriate in cases when the insured persons are obliged to finance the contributions paid later than required by law.
\end{abstract}

Keywords: payment reliefs; contributions financed by the insured persons.

\title{
1. Zakres wyłączenia dopuszczalności stosowania ulg wobec składek finansowanych przez ubezpieczonych
}

W ustawie z dnia 13 października 1998 r. o systemie ubezpieczeń społecznych ${ }^{1}$ przewidziano, że należności z tytułu składek mogą być umarzane w całości lub w części przez ZUS (art. 28 u.s.u.s.). ZUS może także odroczyć termin płatności należności z tytułu składek oraz rozłożyć należność na raty (art. 29 u.s.u.s.). W opracowaniu przyjęto dla uproszczenia szerokie znaczenie pojęcia „ulgi w spłacie składek”, obejmujące zarówno umarzanie (art. 28 u.s.u.s.), jak i odraczanie terminu płatności i rozkładanie należności z tytułu składek na raty (art. 29 u.s.u.s.) $)^{2}$.

Na podstawie art. 30 u.s.u.s. obu powyższych rodzajów ulg nie stosuje się „do składek finansowanych przez ubezpieczonych niebędących płatnikami składek”. Ponadto w art. 29 ust. 1 zdanie drugie u.s.u.s. dodatkowo zastrzeżono, że odroczenie terminu płatności może dotyczyć jedynie należności finansowanej przez płatnika składek. Zapis ten należy interpretować jako potwierdzenie ograniczenia wynikającego z art. 30 u.s.u.s., a nie dorozumiane dopuszczenie zastosowania rozkładania należności

\footnotetext{
Tekst jedn. Dz.U. z 2013 r., poz. 1442 ze zm. (dalej: u.s.u.s.).

Tak np. SN w wyroku z dnia 24 czerwca 2008 r., I UK 360/07, Baza orzeczeń SN, www.sn.pl; mimo że zasadne jest daleko idące rozróżnianie tych instytucji: zob. J. Wantoch-Rekowski, Składki na ubezpieczenia emerytalne - konstrukcja i charakter prawny, Toruń 2005, s. 195-196.
} 
z tytułu składek na raty. Udzielanie ulg w spłacie należności jest wyjątkiem od zasady, że składki opłaca się w wysokości i w terminie wynikającym z przepisów ustawy. Skoro wyjątków nie należy interpretować rozszerzająco, przepis art. 30 u.s.u.s. powinien być traktowany jako wzmocnienie zasady terminowego opłacania składek, szczególnie w części finansowanej przez ubezpieczonych ${ }^{3}$.

Z literalnego i niebudzącego wątpliwości interpretacyjnych brzmienia art. 30 u.s.u.s. wynika, iż regulacje o ulgach w spłacie składek nie znajdują zastosowania w odniesieniu do składek finansowanych przez ubezpieczonych niebędących płatnikami składek. Oznacza to, że tych składek nie dotyczą ulgi w spłacie należności, tj. umorzenie, rozłożenie na raty i odroczenie terminu płatności. Ze sformułowania o braku zastosowania przepisów o ulgach wynika, że nie jest dopuszczalne podejmowanie w stosunku do tych składek jakiegokolwiek merytorycznego rozstrzygnięcia na podstawie art. 28 i 29 u.s.u.s. ${ }^{4}$ Ani przepis art. 28 u.s.u.s., ani przepisy rozporządzenia Ministra Gospodarki, Pracy i Polityki Społecznej z dnia 31 lipca 2003 r. w sprawie szczegółowych zasad umarzania należności z tytułu składek na ubezpieczenia społeczne ${ }^{5}$ nie mogą stanowić podstawy do umorzenia składek należnych za zatrudnianych pracowników w części przez nich finansowanej ${ }^{6}$.

Natomiast należności z tytułu składek na ubezpieczenia społeczne ubezpieczonych będących równocześnie płatnikami składek mogą być objęte ulgą w spłacie, a w uzasadnionych przypadkach umarzane, nawet pomimo braku ich całkowitej nieściągalności (art. 28 ust. 3a u.s.u.s.), właśnie na zasadach określonych w rozporządzeniu z dnia 31 lipca 2003 r. Podobnie co do zasady wszelkie należności z tytułu składek są wyłączone

\footnotetext{
Zob. J. Wantoch-Rekowski, Składki na ubezpieczenia emerytalne..., s. 197. Wyrok SN z dnia 24 czerwca 2008 r., I UK 360/07, Baza orzeczeń SN.

Dz.U. Nr 141, poz. 1365; zgodnie z § 1 rozporządzenia określa ono zasady umarzania przez ZUS należności z tytułu składek na ubezpieczenia społeczne ubezpieczonych będących równocześnie płatnikami tych składek.

6 Por. wyrok NSA z dnia 12 stycznia 2011 r., II GSK 17/10, Centralna Baza Orzeczeń Sądów Administracyjnych (CBOSA); wyrok Wojewódzkiego Sądu Administracyjnego w Warszawie z dnia 18 grudnia 2006 r., III SA/Wa 2923/06, CBOSA.
} 
z postępowania układowego ${ }^{7}$. Jednak na podstawie art. 25 ust. 2 u.s.u.s. ZUS może wyrazić zgodę na objęcie układem należności z tytułu składek finansowane wyłącznie przez płatnika składek. Oznacza to, że nie mogą być objęte układem należności z tytułu składek finansowane przez ubezpieczonych $^{8}$.

Należy również zwrócić uwagę na art. 24 ust. 9 u.s.u.s., zgodnie z którym odsetki za zwłokę, koszty egzekucyjne oraz dodatkowa opłata finansowane są w całości z własnych środków przez płatnika składek. A zatem koszty te powinny być zawsze finansowane przez niesumiennych płatników ${ }^{9}$. Natomiast art. 30 u.s.u.s. dotyczy jedynie składek, a nie szerszego pojęcia „należności z tytułu składek”. Można więc zastosować art. 28 u.s.u.s. wobec pozostałych elementów składających się na ustawowo zdefiniowane pojęcie „należności z tytułu składek”, w tym odsetek ${ }^{10}$.

Interesujący jest wątek sposobu traktowania składek finansowanych przez ubezpieczonych w ustawach szczególnych do u.s.u.s. Mogą one zawierać przepisy dotyczące nieopłaconych składek. W przeszłości regulowały one kwestie restrukturyzacji finansowej różnych sektorów gospodarki i przewidywały m.in. możliwość umarzania składek, czy też stosowania ulg w ich opłacaniu ${ }^{11}$. Zapisy niektórych ustaw były niejasne. Stawały się one coraz bardziej precyzyjne i zmierzały do wyłączania składek finansowanych przez ubezpieczonych ${ }^{12}$ i składek na ubezpieczenia emery-

7 Określonego w ustawie z dnia 28 lutego 2003 r. - Prawo upadłościowe i naprawcze (tekst jedn. Dz.U. z 2012 r. poz. 1112 ze zm.).

8 Zob. D. Wajda [w:] B. Gudowska, J. Strusińska-Żukowska (red.), Ustawa o systemie ubezpieczeń społecznych. Komentarz, Warszawa 2011, s. 436.

9 Ł. Prasołek [w:] B. Gudowska, J. Strusińska-Żukowska (red.) Ustawa o systemie ubezpieczeń społecznych..., s. 435.

10 Wyrok WSA w Warszawie z dnia 31 października 2007 r., V SA/Wa 1816/07, CBOSA.

11 J. Wantoch-Rekowski, Składki na ubezpieczenia emerytalne..., s. 59; M. Łabanowski, Składki na ubezpieczenia społeczne i ich wpływ na gospodarkę finansowq przedsiębiorców [w:] A. Borodo (red.) Zagadnienia prawne i ekonomiczne systemu emerytalnego, Toruń 2004, s. 95-97.

12 Np. art. 2 ust. 1 ustawy z dnia 14 lipca 2000 r. o restrukturyzacji finansowej górnictwa siarki (Dz.U. Nr 74, poz. 856 ze zm.), zgodnie z którym „odracza się spłatę zobowiązań jednostek z tytułu składek na ubezpieczenie społeczne, które, zgodnie z odrębnymi przepisami, są pokrywane ze środków tych jednostek”. 
talne $^{13}$. W uproszczeniu, ulgi nie dotyczyły składek, które finansuje ubezpieczony (pracownik).

W nowszych tzw. ustawach antykryzysowych przyjęto odmienną koncepcję. Pomoc obejmuje przyznawanie środków na opłacenie składek, w części finansowanej przez pracownika ${ }^{14} \mathrm{i}$ w części finansowanej przez pracodawcę $^{15}$. Można jednak mówić o pewnej kontynuacji przyjętego podejścia sprowadzającego się do szczególnej ochrony składek finansowanych przez ubezpieczonych niebędących płatnikami składek, do których nie stosuje się ulg w spłacie, jeżeli miałoby to niekorzystnie wpływać na ich sytuację. Raczej pomaga się zapewnić bieżące opłacanie składek, co wydaje się lepszym rozwiązaniem z punktu widzenia ubezpieczeń społecznych.

Regulacje tego typu są zmienne w czasie i dotyczą szczególnych sytuacji. Nie mogą więc być wykorzystywane jako argument przeciwko temu, żeby ponownie zastanowić się nad funkcją i zakresem wyłączenia przewidzianego w art. 30 u.s.u.s.

Elementem różniącym część składki finansowaną przez płatnika składek (pracodawcę) od części finansowanej przez ubezpieczonego (pracownika) jest źródło finansowania (opłacania) ${ }^{16}$. Część finansowana przez pracownika potrącana jest z jego przychodu. Część finansowana przez pracodawcę opłacana jest z jego zasobów i zwiększa koszty działalności pracodawcy. Dlatego przewidziane w art. 28 i 29 u.s.u.s. mechanizmy ułatwiające spłatę dotyczą tylko tej części składki, którą finansuje płatnik

13 Zob. J. Wantoch-Rekowski, Składki na ubezpieczenia emerytalne..., s. 191 i n.

14 Art. 5 ust. 1 pkt 1 i ust. 2 pkt 1 ustawy z dnia 11 października 2013 r. o szczególnych rozwiązaniach związanych z ochroną miejsc pracy (Dz.U., poz. 1291), który przewiduje finansowane ze środków Funduszu Gwarantowanych Świadczeń Pracowniczych świadczenie na częściowe zaspokojenie wynagrodzenia za czas przestoju ekonomicznego do wysokości 100\% początkowego zasiłku dla bezrobotnych „zwiększonego o wysokość składek na ubezpieczenia społeczne należnych od pracownika”; art. 14 ust. 1 pkt 1 i ust. 3 oraz art. 18 ustawy z dnia 1 lipca 2009 r. o łagodzeniu skutków kryzysu ekonomicznego dla pracowników i przedsiębiorców (Dz.U. Nr 125, poz. 1035 ze zm.).

15 Art. 5 ust. 3 ustawy o szczególnych rozwiązaniach związanych z ochroną miejsc pracy: przedsiębiorcy, w okresie przestoju ekonomicznego lub obniżonego wymiaru czasu pracy, przysługują z FGŚP środki na opłacenie składek na ubezpieczenia społeczne pracowników należnych od pracodawcy.

16 J. Wantoch-Rekowski, Składki na ubezpieczenia emerytalne..., s. 103. 
składek. Ich zastosowanie dotyczy własnych środków płatnika składek, który narusza swój ustawowy obowiązek. Ulgi w spłacie nie mogą być stosowane do składek finansowanych przez pracownika, który - po potrąceniu składek przez płatnika - poniósł ekonomiczny ciężar ich uiszczenia. Wtedy powstaje kwestia odpowiedzialności płatnika składek, a nie „unicestwienia” lub „odroczenia” składek ${ }^{17}$.

W art. 28-30 u.s.u.s. nie wyodrębniono poszczególnych rodzajów ubezpieczeń, mimo że rządzą się one różnymi zasadami: ani przedmiotowo ze względu na rodzaj ryzyka, ani ze względu na ich obowiązkowy lub dobrowolny charakter ${ }^{18}$. Problem dotyczy głównie ubezpieczeń obowiązkowych, ale również ubezpieczeń dobrowolnych. Wprawdzie zgodnie z art. 14 ust. 2 pkt 2 u.s.u.s. ubezpieczenia dobrowolne ustają od pierwszego dnia miesiąca kalendarzowego, za który nie opłacono w terminie składki, ale dotyczy to jedynie osób prowadzących pozarolniczą działalność i osób z nimi współpracujących, duchownych oraz osób wymienionych w art. 7 u.s.u.s. Pozostaje zatem kwestia osób ubezpieczonych dobrowolnie z innych tytułów, za które z różnych przyczyn nie opłacono składki na chorobowe ubezpieczenie dobrowolne finansowanej przez ubezpieczonego.

Silna ochrona spełnienia obowiązku składkowego w części finansowanej przez ubezpieczonych bywa wiązana z przekazywaniem składek na ubezpieczenie emerytalne do otwartych funduszy emerytalnych, szczególnie ze względu na wymóg, że do OFE przekazywane są tylko składki opłacone $^{19}$ i z uwagi na poprzednie brzmienie art. 22 ust. 3 u.s.u.s. ${ }^{20}$ wska-

\footnotetext{
Tamże, s. 181.

8 Por. M. Szczepańska-Bębenek, Opinia prawna na temat poselskiego projektu ustawy o zmianie ustawy o systemie ubezpieczeń społecznych (druk $n r$ 137), Warszawa, 24 kwietnia 2014 r., www.sejm.gov.pl (dostęp: 15.07.2014 r.), s. 5.

19 Przekazanie składki do OFE przez ZUS następuje niezwłocznie, nie później jednak niż w ciągu 15 dni roboczych, licząc od otrzymania składki (art. 47 ust. 9 u.s.u.s.). Do OFE i na subkonto odprowadza się również odsetki za zwłokę wyegzekwowane przez ZUS od tej części składki (art. 23 ust. 2 u.s.u.s.).

20 Obecnie, po zmianie dokonanej ustawą z dnia 25 marca 2011 r. o zmianie niektórych ustaw związanych z funkcjonowaniem systemu ubezpieczeń społecznych (Dz.U. Nr 75, poz. 398), art. 22 ust 3 u.s.u.s. nie określa źródła finansowania części składki przekazywanej do OFE.
} 
zujące, że przekazywane środki pochodzą ze składki ubezpieczonego, a więc wykazujące bliski związek z brzmieniem art. 30 u.s.u.s. („składki finansowane przez ubezpieczonych niebędących płatnikami składek”). Zmiana daty przekazania składki do OFE, szczególnie przy braku przekazywania do OFE odsetek związanych z opóźnieniem, może negatywnie oddziaływać na sytuację ubezpieczonego w wyniku zmian wartości jego środków zgromadzonych w OFE ${ }^{21}$.

Podobnie jest w przypadku składek na ubezpieczenie zdrowotne, do których w zakresie ulg i umorzeń stosuje się odpowiednio przepisy dotyczące składek na ubezpieczenia społeczne (art. 32 u.s.u.s.), a więc i art. 30 u.s.u.s. Przepis art. 30 u.s.u.s. sprawia, że nie można ulg i umorzeń zastosować do składki na ubezpieczenie zdrowotne za osoby niebędące płatnikami składek, gdyż jest ona zwykle finansowana przez ubezpieczonych ${ }^{22}$. Ponadto spełnienie obowiązku ubezpieczenia zdrowotnego jest powiązane ze zgłoszeniem do ubezpieczenia zdrowotnego oraz opłaceniem składki w terminie i na zasadach określonych w ustawie ${ }^{23}$. Mimo więc przepisu przewidującego, że od nieopłaconych w terminie składek na ubezpieczenie zdrowotne pobiera się odsetki za zwłokę na zasadach i w wysokości określonych dla zaległości podatkowych ${ }^{24}$, nieprawidłowe opłacenie składek narusza ustawowe konstrukcje ubezpieczenia zdrowotnego.

Mniej uwagi przywiązywano do składek na ubezpieczenie chorobowe. Zwrócono jednak uwagę, że w ubezpieczeniu chorobowym, finansowanym przez ubezpieczonego, prawo do świadczeń jest powiązane z założeniem opłacania składek, zapewnianym przez art. 30 u.s.u.s. ${ }^{25}$ Jednak $^{2}$ formalnie przesłanką uprawnień jest objęcie ubezpieczeniem. Wysokość świadczeń (podstawa wymiaru zasiłków) zależy od podstawy wymiaru

21 Uwagi SN i Prezesa ZUS do poselskiego projektu ustawy o zmianie ustawy o systemie ubezpieczeń społecznych, druk sejmowy nr 137; M. Szczepańska-Bębenek, Opinia..., s. 5.

22 Zob. art. 84-86 ustawy z dnia 27 sierpnia 2004 r. o świadczeniach opieki zdrowotnej finansowanych ze środków publicznych (tekst jedn. Dz.U. z 2008 r., Nr 164, poz. 1027 ze zm., dalej: u.ś.o.z.).

Art. 67 ust. 1 u.ś.o.z.

Art. 87 ust. 3 u.ś.o.z.

M. Szczepańska-Bębenek, Opinia..., s. 5. 
składek na ubezpieczenia chorobowe ${ }^{26}$, a nie od ich rzeczywistego opłacenia przez płatnika składek. Podobnie określone są warunki przyznawania świadczeń rentowych i ustalania ich wysokości.

W ubezpieczeniach chorobowym i rentowych pozycja ubezpieczonego nie jest więc zależna od ewentualnego zastosowania ulgi w spłacie składek, co może wpływać na ocenę celowości obecnej konstrukcji wynikającej z art. 30 u.s.u.s. Być może dlatego na stronie internetowej ZUS podano informacje, że rozłożeniu na raty ${ }^{27}$ i odroczeniu ${ }^{28}$ podlegają składki na „ubezpieczenia społeczne - z wyłączeniem kwot odpowiadających wysokości składki na ubezpieczenie emerytalne za zatrudnionych pracowników lub innych ubezpieczonych niebędących płatnikami składek na własne ubezpieczenia (np. zleceniobiorców, nakładców)”. Z ulg wyłącza się więc tylko składki na ubezpieczenie emerytalne. Zainteresowany ulgą płatnik składek nie musi, przed skorzystaniem z niej, opłacić składek na ubezpieczenia rentowe i chorobowe finansowanych przez ubezpieczonych. Natomiast płatnik składek zainteresowany umorzeniem składek ma wcześniej opłacić finansowane przez ubezpieczonych składki na ubezpieczenia emerytalne, rentowe, chorobowe i zdrowotne. Według informacji ZUS umorzeniu mogą bowiem podlegać „składki na ubezpieczenia społeczne z wyłączeniem kwot finansowanych przez ubezpieczonych niebędących płatnikami składek na własne ubezpieczenia (np. pracowników, zleceniobiorców)”’29. Zatem mimo brzmienia przepisu art. 30 u.s.u.s. nieróżnicującego zakresu wyłączenia stosowania różnych rodzajów ulg, w praktyce dochodzi do takiego zróżnicowania. Można, jak się wydaje, wiązać to z brakiem negatywnych konsekwencji dla ubezpieczonego w przypadku późniejszego opłacenia składek na ubezpieczenia rentowe i chorobowe.

26 Art. 36 i 48 w zw. z art. 3 pkt 3 i 4 ustawy z dnia 25 czerwca 1999 r. o świadczeniach pieniężnych z ubezpieczenia społecznego w razie choroby i macierzyństwa (tekst jedn. Dz.U. z 2014 r., poz. 159).

27 Rozłożenie spłaty zadłużenia na raty, http://e-inspektorat.zus.pl/sprawy.asp?id_profilu= 1\&pomoc=3\&amp;menu=3\&id_sprawy=368 (dostęp: 15.07.2014 r.).

28 Odroczenie terminu płatności składki, http://e-inspektorat.zus.pl/sprawy.asp?id_profilu= 1\&pomoc=3\&amp;menu=3\&id_sprawy=369 (dostęp: 15.07.2014 r.).

29 Umorzenie należności z tytułu składek, http://e-inspektorat.zus.pl/sprawy.asp?id_profilu= 1\&pomoc=3\&amp;menu=3\&id_sprawy=212 (dostęp: 15.07.2014 r.). 
Nawet w ubezpieczeniu emerytalnym stopniowo słabnie oddziaływanie argumentacji na rzecz szczególnego traktowania składek finansowanych przez ubezpieczonego, która odwołuje się do sytuacji ubezpieczonego będącej wynikiem rzeczywistego wpłacenia składek. W przypadku ubezpieczonych niebędących płatnikami składek od 1 stycznia 2003 r. $^{30}$ na koncie ubezpieczonego w ZUS przechowywane są informacje o składkach należnych, a nie opłaconych (art. 40 ust. 1 pkt 1 u.s.u.s.) ${ }^{31}$, finansowanych zarówno przez płatnika składek, jak i przez ubezpieczonego. Natomiast odwoływanie się do sytuacji ubezpieczonego jako członka OFE traci na znaczeniu ze względu na dobrowolność przekazywania środków do OFE (art. 39 ust. 1 u.s.u.s.). Można więc twierdzić, że jeżeli ustawodawca umożliwia ubezpieczonemu podjęcie decyzji o przeznaczeniu części składki na ubezpieczenie emerytalne, to powinien przyjąć, że ubezpieczony byłby również w stanie podjąć decyzję o ewentualnym ubieganiu się o zastosowanie ulgi w spłacie składek lub wyrażeniu zgody na ubieganie się o taką ulgę przez płatnika składek. Jednak w dalszym ciągu za koniecznością rzeczywistej i terminowej wpłaty składek finansowanych przez ubezpieczonych przemawia to, że na subkoncie ewidencjonuje się informacje o zwaloryzowanej wysokości wpłaconych składek (wraz z wyegzekwowanymi od tych składek odsetkami za zwłokę) ${ }^{32}$, a o przekazaniu środków do OFE nadal decyduje wpłacenie składek.

\section{Konsekwencje wyłączenia dopuszczalności stosowania ulg wobec składek finansowanych przez ubezpieczonych}

Składki finansowane przez ubezpieczonego nie mogą być objęte ulgą (art. 30 u.s.u.s.). Dlatego też, aby uzyskać ulgę w spłacie zaległych należności, przedsiębiorca musi najpierw uregulować zadłużenie z tytułu składek

\footnotetext{
30 Art. 1 pkt 18 lit. a ustawy z dnia 18 grudnia 2002 r. o zmianie ustawy o systemie ubezpieczeń społecznych oraz o zmianie niektórych innych ustaw, Dz.U. Nr 241, poz. 2074.

31 M. Łabanowski, Składki na ubezpieczenia społeczne..., s. 94.

32 Art. 40a ust. 1 u.s.u.s.
} 
w części finansowanej przez ubezpieczonych. W literaturze wskazywano ${ }^{33}$, że przedsiębiorcy przyzwyczajeni do rozwiązań sprzed reformy ubezpieczeń społecznych rozpoczętej w 1999 r. oczekiwali, by również na podstawie obecnych przepisów możliwe było objęcie ulgą całości zaległych należności z tytułu składek na ubezpieczenia społeczne (należności głównej i odsetek), niezależnie od źródła finansowania składki.

Zwrócono jednak uwagę ${ }^{34}$, że rozporządzenia dotyczące rozliczania składek $^{35}$ są niespójne z u.s.u.s. Rozporządzenie Rady Ministrów z dnia 18 kwietnia 2008 r. nie uwzględnia różnych źródeł finansowania składek i w § 12 nakazuje w pierwszej kolejności rozliczać opłaconą w zaniżonej wysokości składkę na pokrycie należnych składek na fundusz emerytalny i na otwarte fundusze emerytalne, proporcjonalnie do należnych kwot. Dotyczy to i części finansowanej przez płatnika, i części finansowanej przez ubezpieczonego. W efekcie nie może wystąpić zadłużenie $\mathrm{z}$ tytułu składek w części finansowanej przez płatnika składek przy braku zadłużenia z tytułu składek w części finansowanej przez ubezpieczonych.

Problem ten jest szczególnie złożony, jeżeli płatnik składek potrąca z przychodów ubezpieczonych składki we właściwej wysokości i przekazuje je do ZUS, ale nie reguluje składek w części finansowanej przez płatnika składek. Nawet przy prawidłowym postępowaniu płatnika składek, polegającym na potrąceniu z przychodów ubezpieczonych należnych składek, sposób rozliczenia tych wpłat sprawia, że płatnik składek będzie jednak zadłużony również z tytułu składek w części finansowanej przez ubezpieczonych. Podstawowy warunek ulgi, czyli nieposiadania zaległości finansowanych przez ubezpieczonych, nie jest możliwy do spełnienia. Żadna wpłata nie może być bowiem zaliczona w całości na te należności. Dlatego ZUS, „rozumiejąc sytuację”, uznaje, że warunek jest spełniony, jeżeli przedsiębiorca ubiegający się o ulgę wpłaci kwotę odpowiadającą wysokością kwocie składek w części

\footnotetext{
M. Łabanowski, Składki na ubezpieczenia społeczne..., s. 89-94.

Tamże, str. 93-94.

Obecnie rozporządzenie Rady Ministrów z dnia 18 kwietnia 2008 r. w sprawie szczegółowych zasad i trybu postępowania w sprawach rozliczania składek, do których poboru jest zobowiązany Zakład Ubezpieczeń Społecznych (Dz.U. Nr 78, poz. 465 ze zm.).
} 
finansowanej przez ubezpieczonych. Ten schemat stosowany jest dopiero po wystąpieniu płatnika składek z wnioskiem o udzielenie ulgi i nie zmienia rozliczenia wpłat już dokonanych przez płatnika składek ${ }^{36}$.

\section{Przedstawione propozycje zmian legislacyjnych}

W Sejmie w 2009 r. $^{37}$ i w 2011 r. $^{38}$ składane były poselskie projekty zmiany art. 30 u.s.u.s. polegające na wykreśleniu z jego treści odwołania do art. 29 u.s.u.s. i w związku z tym dopuszczeniu odroczenia terminu płatności lub rozłożenia na raty również składki na ubezpieczenia społeczne finansowanej przez ubezpieczonego. Projekty zakładają umożliwienie stosowania tych ulg do całości zadłużenia i są do siebie bardzo podobne.

Jako główne uzasadnienie projektowanych zmian wskazywano, że obecne brzmienie art. 29 i 30 u.s.u.s. w powiązaniu z przepisami o rozliczaniu składek $^{39}$ bardzo utrudnia płatnikom składek występowanie o wszelkie ulgi w spłacie należności z tytułu składek:

„W praktyce oznacza to, iż nawet jeśli płatnik wpłaci kwotę, która stanowi wg deklaracji część finansowaną przez ubezpieczonych, to w przypadku wystąpienia do Zakładu Ubezpieczeń Społecznych o rozłożenie pozostałego zadłużenia na raty musi jeszcze uregulować składki w części finansowanej przez ubezpieczonego. Obowiązujące przepisy stanowią bardzo duże utrudnienie w skorzystaniu przez płatników składek z ulgi, jaką jest rozłożenie należności na raty. W praktyce płatnik składek zatrudniający pracowników musi w ciągu kilku dni spłacić ponad 50\% swojego zadłużenia, aby uzyskać możliwość spłaty reszty zadłużenia w ratach, dlatego forma spłaty zadłużenia w ratach jest niepopularna”40.

\footnotetext{
M. Łabanowski, Składki na ubezpieczenia społeczne..., s. 94.

Sejm VI kadencji, druk nr 2371.

Sejm VII kadencji, druk nr 137.

39 § 12 rozporządzenia Rady Ministrów w sprawie szczegółowych zasad i trybu postępowania w sprawach rozliczania składek, do których poboru jest zobowiązany Zakład Ubezpieczeń Społecznych.

40 Uzasadnienie poselskiego projektu ustawy o zmianie ustawy o systemie ubezpieczeń społecznych (Sejm VII kadencji, druk nr 137).
} 
Takie uzasadnienie odpowiada więc opisanym już w literaturze problemom. Proponowane zmiany budzą jednak wiele wątpliwości. Słusznie zauważono, że przeszkodą we wprowadzeniu proponowanego rozwiązania jest przede wszystkim niejasny status środków, które byłyby pobrane przez płatnika składek z wynagrodzenia ubezpieczonego z tytułu, z którego jest on ubezpieczony. Płatnik składek (najczęściej pracodawca) wpłaca bowiem do ZUS składki pochodzące w części ze środków, które stanowią własność pracownika, w stosunku do których pracodawca jest jedynie płatnikiem, osobą pośredniczącą w dokonaniu wpłaty. Pracodawca nie powinien więc mieć możliwości decydowania o zmniejszaniu wpływu składek na poszczególne fundusze za ubezpieczonego (pracownika), ani przede wszystkim możliwości korzystania z nieprzysługujących mu środków finansowych potrąconych z wynagrodzenia pracownika, a nieprzekazanych do ZUS ${ }^{41}$. Odroczenie płatności składek lub rozłożenie płatności na raty mogłoby w konsekwencji prowadzić do przyznania płatnikowi składek prawa do dysponowania środkami pochodzącymi z wynagrodzenia ubezpieczonego, wchodzącymi w skład jego majątku do momentu przekazania do ZUS. W związku z tym może ono stanowić naruszenie zasady ochrony własności i innych praw majątkowych sformułowanej w art. 64 ust. 2 Konstytucji ${ }^{42}$.

Można dodać, że zarówno odroczenie terminu płatności należności z tytułu składek, jak i rozłożenie należności na raty mogą nastąpić tylko w formie umowy między ZUS a dłużnikiem, czyli płatnikiem składek (art. 29 ust. 1a u.s.u.s.) ${ }^{43}$. Wyłączenie z tych czynności składek finansowanych przez ubezpieczonych może więc być potraktowane jako przejaw szerszego problemu, jakim jest w przepisach o systemie ubezpieczeń społecznych przyznawanie samym ubezpieczonym bardzo skąpych możliwości działania i samodzielnego kształtowania swej sytuacji prawnej. Przepis art. 30 u.s.u.s. można byłoby odczytać jako takie rozwiązanie, które ma podtrzy-

41 Stanowisko Rady Ministrów wobec poselskiego projektu ustawy o zmianie ustawy o systemie ubezpieczeń społecznych (druk nr 2371), Warszawa, 27 listopada 2009 r., www.sejm.gov.pl, (dostęp: 15.07.2014 r.).

42 M. Szczepańska-Bębenek, Opinia..., s. 8-9.

43 Zob. J. Wantoch-Rekowski, Składki na ubezpieczenia emerytalne..., s. 150. 
mać wyłączanie osoby ubezpieczonego z czynnego działania w sferze finansowania ubezpieczeń społecznych. Skoro nie trzeba zawierać z nim umów, nie wprowadza się go do systemu.

Należy bowiem zwrócić uwagę, że mimo przepisów o rozłożeniu ciężaru finansowania składek na ubezpieczenia społeczne ZUS nie ma instrumentów prawnych, żeby zwrócić się o zapłatę składek bezpośrednio do ubezpieczonego. Regulację szczegółową dotyczącą postępowania egzekucyjnego uogólnia się tak, że zobowiązanym jest zawsze płatnik składek, ubezpieczony tylko wtedy, gdy jest jednocześnie płatnikiem ${ }^{44}$. Również w regulacji nadpłaty ubezpieczonemu nie przyznano samodzielnych kompetencji. Co do zasady nie może on domagać się zwrotu nienależnie opłaconych składek ani od płatnika składek, ani bezpośrednio od ZUS $^{45}$. Wyjątkowo, dopiero w przypadku braku płatnika składek lub jego następcy prawnego, ZUS zawiadamia ubezpieczonego o kwocie nienależnie opłaconych składek w części sfinansowanej przez ubezpieczonego i na jego wniosek zwraca nienależnie opłacone składki (art. 24 ust. $6 f$ u.s.u.s.). Brakuje analogicznego przepisu rozstrzygającego konsekwencje braku płatnika składek przy nieopłaconych składkach na ubezpieczenia społeczne finansowanych przez ubezpieczonego. Ryzyko takiej sytuacji ograniczają wprawdzie przepisy dotyczące zabezpieczenia płatności składek, wyłączenia ich z postępowania układowego oraz ich szczególna pozycja w postępowaniu upadłościowym, ale nie zapobiegają one całkowicie sytuacji, że może okazać się, że składki nie zostały opłacone (np. przed zaprzestaniem działalności gospodarczej przez przedsiębiorcę).

\section{Możliwość ograniczenia wyłączenia $w$ interesie ubezpieczonych}

Rozważając problem ewentualnego stosowania ulg w spłacie składek finansowanych przez ubezpieczonych, należy dokonać rozróżnienia, czy składka została przez płatnika składek potrącona z przychodu ubezpieczo-

44 J. Wantoch-Rekowski, Składki na ubezpieczenia emerytalne..., s. 108-109.

45 I. Jędrasik-Jankowska, Ubezpieczenie emerytalne. Trzy filary, Warszawa 2001, str. 98. 
nego, czy nie oraz czy do zastosowania ulgi miałoby dojść w interesie płatnika składek, czy też na korzyść, na wniosek lub za zgodą ubezpieczonego.

Należy przyjąć, że ewentualne ulgi nie mogą dotyczyć kwot składek już pobranych z przychodów ubezpieczonych. Takie ulgi byłyby w zasadzie stosowane w interesie płatnika składek. Powodowałyby one nieuzasadnione przysporzenie majątkowe po stronie płatnika składek, kosztem ubezpieczonych i Funduszu Ubezpieczeń Społecznych.

W związku z tym, że płatnik składek jest obowiązany obliczać, potrącać z dochodów ubezpieczonych, rozliczać oraz opłacać należne składki za każdy miesiąc kalendarzowy (art. 46 ust. 1 u.s.u.s.), czyli co do zasady nie powinno dochodzić do wypłaty dochodu bez potrącenia i wpłaty do ZUS należnych od niego składek na ubezpieczenia społeczne ${ }^{46}$, ulgi w spłacie mogłyby dotyczyć jedynie „przyszłych” składek od jeszcze niepobranego wynagrodzenia ${ }^{47}$. Sprowadzałyby się więc do odroczenia terminu płatności tych składek. W sensie ekonomicznym oznaczałoby to opóźnienie w udostępnieniu ubezpieczonemu części należnego mu przychodu ze stosunku prawnego stanowiącego tytuł ubezpieczeń społecznych. Nie można więc sobie wyobrazić, by mogło to się dziać jedynie za zgodą ZUS. Konieczna byłaby również zgoda ubezpieczonego. W obecnych realiach społeczno-gospodarczych i w relacjach, w jakich pozostają płatnicy składek (pracodawcy, często z problemami finansowymi - skoro występują o ulgi) i ubezpieczeni (pracownicy) bardzo duże jest ryzyko, że zgoda taka nie byłaby udzielana swobodnie i z pełną świadomością skutków po stronie ubezpieczonych. Ponadto w stosunkach pracy oznaczałaby

46 Por. art. 87 ust. 1 Kodeksu pracy, który również przewiduje odliczanie z wypłacanego wynagrodzenia za pracę składek na ubezpieczenia społeczne. Wierzytelność pracownika z tytułu wynagrodzenia za pracę wygasa w zakresie, w jakim pracodawca odprowadził składki na ubezpieczenie społeczne i zdrowotne oraz zaliczkę na podatek dochodowy od osób fizycznych: wyrok SN z dnia 25 maja 2005 r., I PK 241/04, Baza orzeczeń SN.

47 Nawet gdyby była wymagana zgoda ubezpieczonego np. na umorzenie składek przez niego finansowanych, to sytuacja taka byłaby bardzo zbliżona do współdziałania ubezpieczonego z płatnikiem składek w celu uniknięcia obowiązku opłacania składek, kiedy to ZUS może odmówić zewidencjonowania na koncie ubezpieczonego nieopłaconej składki na ubezpieczenie emerytalne (art. 40 ust. 8 u.s.u.s.). 
ona dysponowanie przez pracownika częścią prawa do wynagrodzenia za pracę, a zgodnie z art. 84 Kodeksu pracy pracownik nie może zrzec się prawa do wynagrodzenia ani przenieść tego prawa na inną osobę. Zgoda na częściowe wypłacenie wynagrodzenia (odpowiadającego składce) w późniejszym terminie, jako mniej korzystna dla pracownika, jest obecnie nieważna. Wynagrodzenie powinno być w całości wypłacone w ustalonym terminie (art. $18 \S 2$ k.p.). Sposobem na zmniejszenie ciężarów składki jest doprowadzenie do obniżenia wynagrodzenia za pracę w jednym z przewidzianych przez prawo pracy trybów albo skorzystanie z rozwiązań antykryzysowych, które obecnie zakładają kontynuację opłacania składek.

Mogą jednak wystąpić rzadkie sytuacje, kiedy kwoty składek finansowanych przez ubezpieczonego nie byłyby jeszcze potrącone, a zastosowanie ulgi działałoby w interesie ubezpieczonego, bezpośrednio jako podmiotu zobowiązanego do sfinansowania składki lub pośrednio, gdy to płatnik składek (np. pracodawca) sfinansowałby całość składki, a następnie wchodziłoby w grę ryzyko dochodzenia od ubezpieczonego roszczeń z tytułu bezpodstawnego wzbogacenia. Sytuacje takie mogą wystąpić, gdy płatnik składek błędnie obliczy składkę na ubezpieczenia społeczne w stosunku do ubezpieczonego, z którym następnie pozostaje lub nie pozostaje w stosunku prawnym stanowiącym tytuł ubezpieczenia ${ }^{48}$ albo gdy ubezpieczony błędnie zawiadomi płatników składek o przekroczeniu kwoty rocznej podstawy wymiaru składek ${ }^{49}$. Z opóźnieniem dochodzi wówczas do ustalenia prawidłowej wysokości należnych składek.

Wydaje się, że w takich sytuacjach wprowadzenie ustawowej możliwości stosowania ulg w spłacie składek finansowanych przez ubezpieczonych niebędących płatnikami składek, analogicznych do dotyczących pozostałych należności z tytułu składek, byłoby uzasadnione. Działałoby

48 Zob. np. R. Pacud, Zobowiq̨zania składkowe w ubezpieczeniach społecznych a zobowiq̨zania podatkowe, [w:] „Studia z zakresu prawa pracy i polityki społecznej” 2012, s. 481-482.

49 Zgodnie z art. 19 ust. 6 u.s.u.s. jeżeli do opłacania składek na ubezpieczenia emerytalne i rentowe jest zobowiązany więcej niż jeden płatnik składek, ubezpieczony jest zobowiązany zawiadomić wszystkich płatników składek o przekroczeniu kwoty rocznej podstawy wymiaru składek. Za skutki błędnego zawiadomienia powodującego nieopłacenie należnych składek na ubezpieczenia emerytalne i rentowe odpowiada ubezpieczony. 
na korzyść ubezpieczonego, jeżeli z różnych powodów składka nie została prawidłowo opłacona, a następnie doszło do zmiany sytuacji ubezpieczonego (np. wysokości przychodów). Wtedy zastosowanie ulgi w spłacie łączyłoby ochronę składek z ochroną bieżących interesów ubezpieczonych.

Można założyć, że jeżeli z wnioskiem występowałby ubezpieczony, byłby on w stanie ocenić wady i zalety zastosowania ulgi w danej sytuacji, łącznie z konsekwencjami dla świadczeń, w szczególności w ubezpieczeniu emerytalnym. Zastosowanie ulg oczywiście nie powinno być dopuszczalne, gdy „błędy” płatnika składek lub ubezpieczonego są wynikiem ich współdziałania w celu uniknięcia obowiązku opłacania składek (por. art. 40 ust. 8 u.s.u.s.).

Ewentualne umożliwienie stosowania ulg w zakresie części składek finansowanych przez ubezpieczonych niebędących płatnikami składek powodowałoby ponadto problem o charakterze podmiotowym. Kwestią wtórną, wymagającą jednak wyraźnego ustawowego uregulowania, byłoby to, kto występowałby w postępowaniu o zastosowanie ulgi. Poselski projekt ustawy złożony w Sejmie (druk nr 137) zakłada, że płatnik. W przedstawionej tu skromniejszej propozycji zmierzającej do stosowania ulg na korzyść ubezpieczonego, a nie płatnika, racjonalnym rozwiązaniem byłoby, żeby był to ubezpieczony. Nie odpowiadałoby to jednak dotychczasowym konstrukcjom systemowym, które zakładają, że to płatnicy składek kontaktują się z ZUS. Od tej zasady występują jednak wyjątki, gdy ubezpieczony samodzielnie dokonuje czynności z zakresu ubezpieczeń społecznych, bez pośrednictwa płatnika składek ${ }^{50}$. Proponowane rozwiązanie dodatkowo służyłoby więc wzmocnieniu pozycji ubezpieczonego w prawie ubezpieczeń społecznych.

\section{Bibliografia:}

Gudowska B., Strusińska-Żukowska, J. (red.), Ustawa o systemie ubezpieczeń społecznych. Komentarz, C.H. Beck, Warszawa 2011.

50 Np. art. 39 u.s.u.s., art. 11 ust. 2 ustawy z dnia 6 grudnia 2013 r. o zmianie niektórych ustaw w związku z określeniem zasad wypłaty emerytur ze środków zgromadzonych w otwartych funduszach emerytalnych (Dz.U. 2013, poz. 1717). 
Jędrasik-Jankowska, I., Ubezpieczenie emerytalne. Trzy filary, Wydawnictwa Prawnicze PWN, Warszawa 2001.

Łabanowski, M., Składki na ubezpieczenia społeczne i ich wpływ na gospodarkę finansowq przedsiębiorców [w:] A. Borodo (red.), Zagadnienia prawne i ekonomiczne systemu emerytalnego, TNOiK, Toruń 2004, s. 87-98.

Pacud, R., Zobowiqzania składkowe w ubezpieczeniach społecznych a zobowiqzania podatkowe [w:] „Studia z zakresu prawa pracy i polityki społecznej” 2012, s. 471-490.

Szczepańska-Bębenek, M., Opinia prawna na temat poselskiego projektu ustawy o zmianie ustawy o systemie ubezpieczeń społecznych (druk nr 137), Warszawa, 24 kwietnia 2014 r., www.sejm.gov.pl.

Wantoch-Rekowski, J., Składki na ubezpieczenia emerytalne - konstrukcja i charakter prawny, TNOiK, Toruń 2005. 